\title{
Montagnier's AIDS report covers all angles
}

Paris. Many scientists who had expressed surprise last May when the French government commissioned Luc Montagnier of the Institut Pasteur to assess the French attack on AIDS were comforted last week when the two fat reports that Montagnier presented to prime minister Edouard Balladur emerged as a comprehensive review containing sensible - if unsurprising - recommendations.

While the French media worship Montagnier, and politicians appear to trust him, many scientists remain sceptical of his scientific ideas. Some had feared that Montagnier would use the responsibility given him by the government to promote his own hypotheses, for example that cofactors such as mycoplasmas increase the pathogenicity of AIDS. Others that he would use the opportunity to settle old scores.

In the event, Montagnier did neither. Indeed, only one-tenth of the report deals with research. The rest deals with prevention, health-care, training, and the particular problems of drug addicts, prison inmates and women. To cover these areas, Montagnier consulted widely, giving rise to speculation that, at 61 years of age, he may be angling for a role as national AIDS coordinator.

The report urges the government to create an interministerial committee to coordinate all its efforts against the epidemic, including research. At present, the health ministry hands out disposable syringes to drug addicts at public points, while the ministry of interior's police often handcuff addicts a few minutes later for possession of syringes.

Montagnier criticizes the National AIDS Research Agency (ANRS), set up in 1989, as a "ghetto" with insufficient links to other areas of scientific research, or to practical AIDS programmes. His remedy is to involve the ministry of health directly in ANRS affairs, and to integrate basic and clinical research by creating joint centres.

ANRS's research portfolio is too conservative, says Montagnier. He wants it to support a greater variety of approaches, and to engage in "permanent brainstorming". To this end, he suggests that Jean-Paul Levy, the agency's director, should consult a panel of scientific advisers on all important decisions, and that the agency should create a special fund of FF50 to FF100 million (US\$8.5 to US\$17 million) to support nonmainstream AIDS research.

Montagnier proposes that in the medium term ARNS should be absorbed into the national medical research organization, INSERM, a move that would be possible once INSERM becomes used to administering strategic research. Another recommendation is that all patients should be given access to promising drugs before these are approved. And he suggests an investigation into illegal clinical trials.

$\mathrm{He}$ also suggests setting up an Institute of Complex Infectious Pathologies to combine research on AIDS with that on other diseases involving infection and the immune system, for example ageing and cancer.

Many scientists and physicians have

\section{IMAGE UNAVAILABLE FOR COPYRIGHT REASONS}

\section{Spreading the word: a 'condom' in Place de la Concorde.}

welcomed Montagnier's report as a timely and common-sense review. But some criticize its lack of concrete proposals. Levy, for example, says that his agency already seeks out new avenues of research, and that the proposed advisory structure would simply "formalize" existing committees.

Similarly the patient group, AIDES, criticizes the report for focusing too much on catching up with the current situation, rather than providing the government with proposals for what might happen in the future.

The group is also concerned that an interministerial committee might complicate and slow down decision-making.

The government is expected to reply to Montagnier's 49 recommendations in January. But it has already benefited from the report. Although scheduled for release earlier in November, it was held back until 1 December, World AIDS Day. As a result, extensive press coverage of the report coincided with visits by ministers to hospitals and AIDS action groups, providing the government with a unique opportunity to demonstrate its concern for the welfare of patients.

Declan Butler

\section{Czech academics get temporary contracts}

Munich. In a move designed to speed up the removal of university faculty members appointed for political rather than intellectual reasons, the Czech government has placed all academics on temporary contracts. They will have to reapply for their posts next year.

The government's move has been supported in principle by the Czech committee of university rectors. But the committee is challenging the way in which the rule is being put into effect, claiming that academic freedom is undermined by the government's role in choosing members of the reselection committees.

The current higher education law, passed in 1990 immediately after the collapse of communism, already allows individual universities to introduce competitive evaluations to check the academic qualifications of their staff.

But according to Josef Splichal, head of the university department in the Ministry of Education, many universities have failed to use this procedure effectively, and there has been little turnover of staff. Splichal also says that many academics chose to accept temporary contracts rather than face selection committees.

Shortly before the summer recess, an amendment to the legislation was hurriedly passed by the Czech Parliament placing all remaining permanent university staff amounting to two-thirds of the 13,000 teachers and researchers - on temporary contracts. These contracts expire at the end of next September, and before then all those affected will have to re-apply for their jobs.

A national competition for choosing professors was launched by the ministry last week. Applicants will be judged by committees made up of ministry representatives and academics selected from nominations submitted by the universities. After the appointment of professors, selection committees will be set up for other academic positions.

Martin Cernohorsky, president of the rectors' committee, accepts that the new procedure is needed to accelerate post-communist reforms. But he strongly disagrees with the way it is being implemented and has written to the ministry, suggesting that university autonomy be retained by letting rectors and deans appoint their own selection committees. Each committee could include a representative from the ministry to observe that procedures were being carried out correctly.

But the ministry has so far refused to accept this suggestion. Splichal claims that, as universities are allowed to nominate candidates for the central selection committees, their autonomy has not been unduly threatened in what he describes as a "transient and unstable period".

University staff will be kept on temporary contracts at least until a new law on universities, now under discussion, is passed. But even under the new law, some of them may not be given permanent positions. And in any case the law is unlikely to be ready, as originally hoped, by next summer.

Alison Abbott 